\title{
The Association between Cryptococcal Antigenemia and CD4+ T lymphocyte Count in HIV/AIDS Patients with Suspected Cryptococcus Infection
}

\author{
Sajuni Widjaja, Erwin Astha Triyono and Arthur Pohan Kawilarang \\ Department of Clinical Medicine, Faculty of Medicine Universitas Airlangga, Dr. Soetomo Teaching Hospital, Jl. Prof \\ Moestopo, Surabaya, Indonesia \\ apji@fk.unair.ac.id
}

Keywords: $\quad$ AIDS, CD4+, Cryptococcal Antigenemia, HIV, T lymphocyte.

\begin{abstract}
Cryptococcus fungal infection in Human Immunodeficiency Virus/Acquired Immune Deficiency Syndrome (HIV / AIDS) patients results in cryptococcal meningitis with a mortality of $100 \%$ if the patients do not receive appropriate antifungal therapy. An examination of cryptococcal antigens will provide risk information for patients who will experience cryptococcal meningitis. This study aimed to determine the proportion of cryptococcal antigenemia in HIV/AIDS patients treated at Dr. Soetomo General Hospital Surabaya and to observe its relation with CD4+ T lymphocyte count. Cryptococcal antigenemia was examined in HIV/AIDS patients with suspected Cryptococcus infection and a CD4+ T lymphocyte count $<200$ cell/ $/ \mu$. The examination used a lateral-flow assay diagnostic tool (a simple diagnostic kit from IMMY that detects the capsular antigen of cryptococcus) and also a fungal culture on sabouraud dextrose agar. There were three positive cryptococcal antigenemia from 41 serum specimens of HIV/AIDS patients with suspected cryptococcus infection and a CD4 $+\mathrm{T}$ cell lymphocyte count $<200$ cell $/ \mu 1$. All the patients were males, aged over 36 years old, had CD4+ T cell lymphocytes $<100 \mathrm{cell} / \mu \mathrm{l}$ and had never received antiretroviral therapy before. The proportion of cryptococcal antigenemia in HIV/AIDS patients with suspected Cryptococcus infection and a CD4+ T cell lymphocyte count $<200$ cell $/ \mu 1$ was $7.32 \%$. There was no significant association of the occurrence of cryptococcal antigenemia with age, gender, symptoms, CD4+ T lymphocyte count and previous ARV status.
\end{abstract}

\section{INTRODUCTION}

HIV/AIDS has so far claimed the lives of humans, mostly humans in their productive age. Death is mainly due to opportunistic infection (Denning, 2016). Opportunistic infection is an infection that will not cause illness in individuals with a healthy immune system. However, it is fatal in people with decreased immunity, as in HIV/AIDS patients. Deaths because of AIDS greatly reduce family incomes, increasing poverty, especially in countries with high HIV/AIDS populations (Denning, 2016).

The statistical data reported that in July until September 2014 in Indonesia, 7,355 new cases were reported. The highest percentage of HIV infections were reported in the age group of 25-49 years old $(69.1 \%)$, followed by the age group of 20-24 years old $(17.2 \%)$, and then the age group of $\geq 50$ years old (5.5\%) (RI., 2014). In 2010, UNAIDS (Joint United
Nations Program on HIV/AIDS) targeted zero deaths due to AIDS in 2015; however, there were still $1,500,000$ individuals who died because of AIDS in 2013 (UNAIDS, 2015). This reduced by $15 \%$ compared with the deaths of 1,760,000 individuals in 2010. There is a total of 360,000 (24\%) deaths/year of AIDS patients due to Tuberculosis. On the other hand, deaths due to fungal infection in AIDS are estimated at 700,000 (47\%)/year (Denning, 2016). The undertaking to reduce opportunistic infections due to fungus can reduce about $30 \%$ of all deaths in AIDS patients. The main causes of death due to fungal infections in AIDS include cryptococcal meningitis, Pneumocystis pneumonia (PCP), disseminated histoplasmosis (DH), and aspergillosis (chronic and invasive) (Denning, 2016). The estimation of AIDS cases related to cryptococcus meningitis worldwide based on 2007 data were 372,000 (Parkes et al., 2011). Most affected patients are in their mid-30s, and if not treated, the mortality

Widjaja, S., Astha Triyono, E. and Pohan Kawilarang, A. 
of cryptococcus infection is $100 \%$. The standard management at the hospital is to focus on the diagnosis of antigen, lumbar puncture and antifungal therapy (Denning, 2016).

The examination of cryptococcal antigenemia will provide risk information for patients who will experience cryptococcal meningitis and death. Therefore, appropriate antifungal administration in patients with positive cryptococcal antigenemia (CrAg) is highly recommended. Rapid diagnostic examination using the LFA (lateral flow immunoassay) method recommended by the WHO in HIV/AIDS patients is also recommended as a screening diagnostic method especially in HIV/AIDS patients with mild symptoms (no neurological disorders) or asymptomatic (Rajasingham et al., 2017).

The global prevalence of Cryptococcal antigenemia is $6 \%$. Ganiem et al. (2014) conducted a study at Hasan Sadikin Hospital, Bandung, Indonesia with a prevalence of $7 \%$ outpatient HIV/AIDS patients with a CD4+ T-cell lymphocyte count $<100$ cells/ $\mu$ l (Rajasingham et al., 2017; Ganiem et al., 2014). More than $80 \%$ positive $\mathrm{CrAg}$ was found in HIV/AIDS patients with CD4+ T cell lymphocyte count $<100$ cells $/ \mu 1$. In other African and American studies, it was also found in HIV/AIDS patients with CD4+ T cell lymphocytes count $100-200$ cell $/ \mu 1$, but rarely found in CD4+ $\mathrm{T}$ cell lymphocytes > 200 cells/ $\mu$ l (Vidal et al., 2016; Alemu et al., 2013). This LFA examination is inexpensive and easy to conduct, giving a result of sensitivity and specificity of $>95 \%$ within 10 minutes. The examination method using LFA has never been conducted in Dr. Soetomo General Hospital Surabaya. Based on this background, the researchers are interested in investigating this field.

\section{METHOD}

This study was conducted on serum specimens from 41 patients with suspected cryptococcus infection (presence of one of the fever/headache symptoms) accompanied by a CD4+ T cell lymphocyte count < 200 cells/ $\mu$ l. The study was conducted in the Infection Disease Intermediate Treatment Unit (UPIPI) and Microbiology Installation Clinic of the Integrated Diagnostic Center of Dr. Soetomo General Hospital, Surabaya during the period of March to June 2017. The sample was collected by using purposive sampling with inclusion criteria of male and female patients over 21 years old, HIV-infected patients with three positive methods, patients with clinical suspected co-infection with Cryptococcus, the presence of fever and/or headache, and HIV/AIDS patients with CD4+ T lymphocytes $<200$ cell $/ \mu$ l. The hypothesis was there is a correlation between cryptococcus antigenemia and CD4 lymphocyte count in HIV/AIDS patients with suspected Cryptococcus infection.

Serum was separated from blood sample, and then according to IMMY manufacturer's recommendation, one drop of lateral flow specimen was added to a microtube, and then $40 \mu \mathrm{l}$ of serum was added to the microtube. After that, a lateral flow strip is applied for 10 minutes. A positive test results if there are two lines on the strip, and is negative if only one line appears. Fungal culture was performed using Sabouraud dextrose agar for 14 days.

This research was observational analytic research with a cross-sectional approach. The study protocol was approved by the Ethical Commission to conduct basic science/clinical research in Dr. Soetomo General Hospital Surabaya. The dependent and independent variable data were analyzed using the Pearson correlation test (if normal distributed data) or Spearman rho correlation test (if the data were abnormally distributed). The whole process of data analysis was processed using SPSS software version 22.0 (SPSS, Inc., Chicago, IL).

\section{RESULTS}

Cryptococcus fungus infection in HIV/AIDS patients is one of the most common opportunistic infections. This study aimed to study the proportion of cryptococcal antigenemia and to analyze the correlation of $\mathrm{CrAg}$ incidence with $\mathrm{CD} 4+\mathrm{T}$ cell lymphocyte count $(<100$ cells $/ \mu 1$ or $100-200$ cells $/ \mu \mathrm{l})$ in HIV/AIDS patients at Dr. Soetomo General Hospital, Surabaya. The samples examined were serum specimens from 41 patients with suspected cryptococcus infection (the presence of one of the fever/headache symptoms) accompanied by a CD4+ $\mathrm{T}$ cell lymphocyte count $<200$ cells/ $\mu$ l. The patients were being treated in the inpatient ward of the Intermediate Treatment Unit of Infectious Diseases of Dr. Soetomo General Hospital.

The total sample size in this study was 41 patients, consisting of four female patients and 37 male patients (Figure 1). The patient age range in this study was 21 years old to 71 years old, with a mean of 36.37 years old. Most age were in the age range 21 to 30 years old, followed by the age range 31 to 40 years old. 
The research samples that had not received antiretroviral drugs were 26 subjects $(63.4 \%)$, while 15 subjects had previously received ARV (36.6\%). The CD4+ T cell lymphocyte count in this study was in the range of 1 cell/ $\mu$ l to 158 cells $/ \mu$ l. The mean CD4+ T cell lymphocyte count was 32.56 cells $/ \mu 1$. The composition of patients based on the CD4+ T lymphocyte count group can be seen in Table 2 .

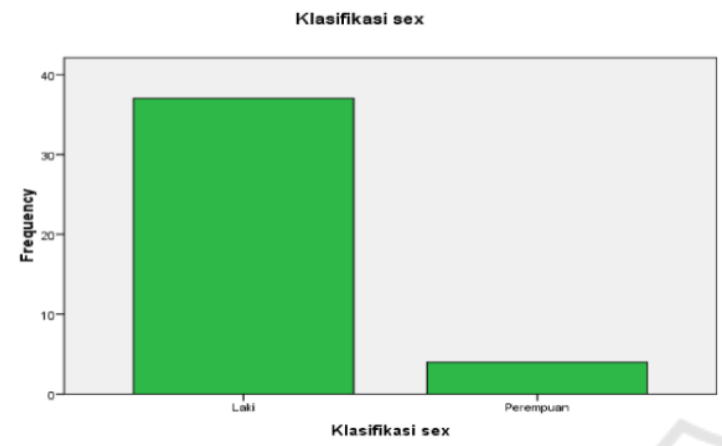

Figure 1: The classification graphic based on gender.

Table 1: Characteristics of age range of HIV/AIDS patients.

\begin{tabular}{ccc}
\hline $\begin{array}{c}\text { Age range } \\
\text { (year) }\end{array}$ & $\begin{array}{c}\text { Total } \\
\text { (individual) }\end{array}$ & $\%$ \\
\hline $21-30$ & 16 & 39 \\
$31-40$ & 14 & 34.1 \\
$41-50$ & 7 & 17.1 \\
$51-60$ & 2 & 4.9 \\
$61-70$ & 1 & 2.4 \\
$>71$ & 1 & 2.4 \\
\hline Total & 41 & 100 \\
\hline
\end{tabular}

Table 2: The characteristics of CD4+ T cells lymphocyte count of the patients.

\begin{tabular}{lll}
\hline $\begin{array}{l}\text { CD4+ T cell lymphocyte count } \\
\text { (cell/ } \mu \mathrm{l})\end{array}$ & Total & $\%$ \\
\hline$<50$ & 34 & 82.9 \\
$50-100$ & 5 & 12.2 \\
$100-150$ & 1 & 2.4 \\
$>150-200$ & 1 & 2.4 \\
\hline Total & 41 & 100 \\
\hline
\end{tabular}

From the 41 patients who underwent the serum cryptococcal antigenemia with LFA method, three positive patients $(7.32 \%$ proportion) were identified. From the three patients with positive cryptococcal antigenemia, one bactec patient was positive on day 1 , but the culture of cryptococcus from bactec in SDA was positive on the tenth day; one other patient was bactec positive on the fifth day, and the culture of cryptococcus from bactec was SDA positive on day 2; no fungus was found in the culture of one other patient. Here is a table of characteristics of comparison between patients with positive and negative cryptococcal antigenemia.

Table 3: Comparison characteristics of patients with positive and negative cryptococcal antigenemia.

\begin{tabular}{|c|c|c|c|}
\hline Parameters & $\begin{array}{c}\text { Positive } \\
\text { CrAg }\end{array}$ & $\begin{array}{c}\text { Negative } \\
\text { CrAg }\end{array}$ & $\mathrm{P}$ \\
\hline \multicolumn{4}{|l|}{ Age (year) } \\
\hline$<36$ & 0 & 22 & 0.091 \\
\hline$>36$ & 3 & 16 & \\
\hline \multicolumn{4}{|l|}{ Gender } \\
\hline $\begin{array}{l}\text { Male } \\
\text { Ma }\end{array}$ & 3 & 34 & 1.000 \\
\hline Female & 0 & 4 & \\
\hline \multicolumn{4}{|l|}{ Fever Symptom } \\
\hline Yes & 2 & 37 & 0.143 \\
\hline No & 1 & 1 & \\
\hline \multicolumn{4}{|l|}{ Headache symptom } \\
\hline Yes & 3 & 25 & 0.539 \\
\hline No & 0 & 13 & \\
\hline \multicolumn{4}{|c|}{ CD4+ T cells Lymphocyte Count } \\
\hline $\begin{array}{l}<100 \mathrm{cell} / \mu \mathrm{l} \\
\end{array}$ & 3 & 36 & 1.000 \\
\hline$>100 \mathrm{cell} / \mu \mathrm{l}$ & 0 & 2 & \\
\hline ARV & 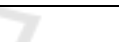 & & \\
\hline Yes & 0 & 15 & 0.287 \\
\hline Never & 3 & 23 & \\
\hline
\end{tabular}

In this study, there was no significant difference between positive and negative $\mathrm{CrAg}$ for the characteristics of age, gender, symptoms, CD4+ Tcell lymphocyte count and whether or not ARV was received. There were cultured colonies which were mucoid textured and colored white to cream. In LCB coloring and Indian ink, yeast cells appeared, spherical and irregular, with capsule formation around the cells.

\section{DISCUSSION}

Cryptococcosis is a disease caused by Cryptococcus fungi that has a unique polysaccharide capsule. This unique glucuronoxylomannan polysaccharide capsule is the diagnostic target in identifying the presence of cryptococcal antigen (CrAg) (Kozel and Bauman, 2012). CrAg detection is a very sensitive diagnostic test for cryptococcosis (Perfect \& Bicanic, 2014). There are several methods of CrAg inspection, but a superior inspection method that meets WHO criteria is using the LFA method (Vidal et al., 2016). Because of the superiority of CrAg LFA compared to other $\mathrm{CrAg}$ immunoassay tests, the writers used CrAg LFA when conducting the study. 
Table 4: The patient characteristics with positive CrAg.

\begin{tabular}{|c|l|l|l|l|l|l|l|l|}
\hline Patient & Gender & $\begin{array}{c}\text { Age } \\
(\text { years })\end{array}$ & Fever & Headache & $\begin{array}{c}\text { CD4 } \\
(\text { cell/ } \mu \mathrm{l})\end{array}$ & $\begin{array}{c}\text { ARV } \\
\text { history }\end{array}$ & $\begin{array}{c}\text { Blood } \\
\text { culture }\end{array}$ & Diagnosis \\
\hline 1 & M & 71 & No & Yes & 34 & No & Positive & $\begin{array}{l}\text { AIDS + COPD exacerbations + } \\
\text { Sepsis }+\begin{array}{r}\text { Suspected } \\
\text { Toxoplasmosis }\end{array}\end{array}$ \\
\hline 2 & M & 54 & Yes & Yes & 97 & No & Negative & $\begin{array}{l}\text { AIDS + CAP + sepsis + AKI + } \\
\text { periappendicular mass }\end{array}$ \\
\hline 3 & M & 42 & Yes & Yes & 5 & No & Positive & $\begin{array}{l}\text { AIDS + PCP + breath failure type } \\
\text { I + oropharynx candidiasis }\end{array}$ \\
\hline
\end{tabular}

There were three positive LFA CrAgs from 41 serum specimens examined. The criteria of 41 patients regarding serum CrAg LFA examination had a CD4+ T lymphocyte count below 200 cells/ $\mu$ land had clinical symptoms of fever and/or headache. The symptoms of fever and headache are common symptoms in patients with cryptococcosis (Alemu et al., 2013; Ganiem et al., 2014; Manga et al., 2016). The proportion of $7.32 \%$ in this study was found. This is in accordance with the global average prevalence of cryptococcal antigenemia of 6\% (95\% CI 5.8-62) (Rajasingham et al., 2017).

A 3\% prevalence of cryptococcal antigenemia is the point at which the cost of treating cryptococcal meningitis with amphotericin B is greater than the cost of screening for CrAg examination. In Uganda, the screening to prevent one case of cryptococcal meningitis costs $\$ 28$, while preventing one death due to cryptococcal meningitis costs \$40 (Meya et al., 2010). The golden standard treatment for cryptococcal meningitis uses amphotericin B and flucytosine which are known to be expensive and difficult to obtain especially by low-income countries; thus, fluconazole is more often used (Parkes et al., 2011). Other studies reported that CrAg screening in areas with a prevalence of $<1 \%$ remained "cost-effective" due to lower LFA screening costs compared with CrAg-latex (Rajasingham et al., 2017; Meya et al., 2010)

Not all of the patients with cryptococcal antigenemia will develop cryptococcal meningitis. Several studies suggest that about $70 \%(56-84 \%)$ of patients with cryptococcal antigenemia will result in cryptococcosis or die without a diagnosis if they are not given antiretroviral treatment or fluconazole for prevention (Rajasingham et al., 2017. Meya et al., 2010). The incidence of cryptococcal meningitis in HIV/AIDS patients with a CD4+ T cell lymphocyte count $<200$ cells $/ \mu$ l initially with no cryptococcal antigenemia prior to ARV therapy is 5.14 per 100 individuals-year (estimated 2.6-9.0 events per 100 individuals-year) (Parkes et al., 2011). In highincome countries, the risk of cryptococcal meningitis is $50 \%$ lower (2.57 incidents per 100 individuals-year $<$ estimated 1.3-4.5 events per 100 individuals-year). This may be due to more intense viral load monitoring and the inclusion of second-line antiretroviral options (Rajasingham et al., 2017).

It is estimated that in low-income countries, the one-year mortality rate due to cryptococcal meningitis in those who have received treatment is $70 \%$, whereas in those with no treatment, it is $100 \%$ (Mfinanga et al., 2015; Govender et al., 2015). In medium-income countries, an estimated one-year mortality rate is $40 \%$ in patients receiving amphotericin B and fluconazole therapy, and $60 \%$ in untreated patients (e.g. do not receive ARV therapy) (Rajasingham et al., 2017; Vidal et al., 2013).

It is estimated that there are about 223,100 cases of cryptococcal meningitis globally which is about $73 \% \quad(162,500 \quad[95 \%$ CI $113.600-193.900])$ that occurs in sub-Saharan Africa. The region with the second highest incidence is the Asia Pacific (19\% of the total), with an annual incidence of 43,200 (95\% CI 25,300-64,700) cases of cryptococcal meningitis. The countries with the highest incidence of cryptococcal meningitis include Nigeria, South Africa, Mozambique, India, Uganda, Ethiopia, Kenya, Tanzania, DR Congo, Zimbabwe, Indonesia and Zambia (Rajasingham et al., 2017). The prevalence of different cryptococcosis is due to geographic differences, temperature, humidity and altitude above sea level (Tensini et al., 2016). In Southeast Asia, the prevalence of $\mathrm{CrAg}$ in HIV/AIDS patients who have never received antiretroviral therapy with a CD4+ T cell lymphocyte count $<100$ cells/ $\mu$ is $4-12.9 \%$ (Kaplan et al., 2015).

Indonesia is included in the countries with a high incidence of cryptococcal meningitis. The results of a cohort study conducted at Hasan Sadikin Hospital, Bandung, Indonesia were found to be $58(7.1 \%)$ of a total of 810 patients who had positive cryptococcal 
antigen test results. After one year of follow up, death (22.4\% vs. $11.6 \% ; \mathrm{p}=0.016)$ and the end-of-death outcomes and no return for control combination (67.2\% vs. $40.4 \%$; $p<0.001)$ were higher in patients with positive cryptococcal antigen (Ganiem et al., 2014).

Most of the patients in this study were males with 37 of 41 total samples $(90.2 \%$ of total patients) and with three of 37 patients having positive cryptococcal antigenemia. These data are similar to the data obtained in several other studies. The prevalence of males against females can be explained by the higher incidence of HIV in males. The host gender also plays a role in the pathogenesis of cryptococcal infections, in which estrogen can inhibit the growth of cryptococcus in vitro. Male immune responses are less efficient in controlling cryptococcus infections because male macrophages tend to be killed by cryptococcus rather than phagocytosis of cryptococcus (Alemu et al., 2013; McClelland and Hobbs, 2013). The opposite was found in other studies conducted at the Dakar Hospital, Senegal, involving 541 patients, who had a positive $\mathrm{CrAg}$ prevalence of $9.2 \%$ with a higher ratio of females to males (Manga et al., 2016).

In this study, there was no correlation of gender (male/female) with the occurrence of cryptococcal antigenemia (positive/negative) with a $p$ value of 1.0. Manga et al. (2016) obtained a p value of 0.3, Ganiem et al. (2014) obtained a p value of 0.471 , while Alemu et al. (2013) obtained a p value of 0.05 . Alemu et al. conducted a study involving 369 HIV patients aged over 18 years old with a CD4+ T cell count $\leq 200$ cells $/ \mu$ who routinely came to the clinic. Manga et al. conducted a study involving 236 patients with criteria of the study subjects of HIV patients aged over 15 years old who entered the hospital (Alemu et al., 2013; Ganiem et al., 2014). Ganiem et al. conducted a study involving 810 patients with criteria of HIV patients who had never received antiretroviral therapy with a CD4+ T cell lymphocyte count $<100$ cell $/ \mu 1$. The patient age range in this study was 21 years to 71 years old, with a mean of 36.37 years old. Most were in the age range 21 to 30 years old, followed by the second most common age range of 31 to 40 years old. The age of $\mathrm{CrAg}$ positive patients and negative $\mathrm{CrAg}$ was not significant in this study, with a $p$ value of 0.091 . This was also obtained in a study conducted by Manga et al. (2016) with a p value of 0.2 and in a study conducted by Ganiem et al. (2014) with a p value of 0.345 . The significance of age to positive $\mathrm{CrAg}$ was found in a study conducted by Alemu et al. (2013) with a p value of 0.04 (Ganiem et al., 2014; Alemu et al., 2013; Manga et al., 2016).
The prognosis of cryptococcosis occurring in patients aged $>60$ years old is generally worse. In this study, one patient was 71 years old and the other patients were 42 and 54 years old. The first patient aged >60 years old after 17 days of treatment died, while two other patients recovered. The clinical symptoms in patients with $\mathrm{CrAg}$ positive and $\mathrm{CrAg}$ negative in this study were not statistically significant ( $p=0.143$ for fever symptoms, and $\mathrm{p}=0.539$ for headache symptoms). Manga et al. (2016) obtained a $p$ value of 0.5 for fever symptoms, and $p<0.05$ (the significance of symptom differences between $\mathrm{CrAg}$ positive and $\mathrm{CrAg}$ negative) for headache symptoms, decreased consciousness and meningeal excitatory (Manga et al., 2016). Research conducted by Ganiem et al. (2014) obtained a $p$ value of 0.884 for fever, $p$ value of 0.789 for coughing for more than 1 week and p value of 0.969 for weight loss $>10 \%$ (Ganiem et al., 2014). Research conducted by Alemu et al. (2013) obtained a $p$ value of 0.053 for fever, $p$ value of 0.92 for headache, $p$ value of 0.24 for stiff neck, $p$ value of 0.61 for mental status change, $p$ value of 0.55 for photophobia, $\mathrm{p}$ value of 0.18 for nausea, $\mathrm{p}$ value of 0.65 for night sweats, $p$ value of 0.80 for coughing, $p$ value of 0.35 for vomiting and $p$ value of 0.09 for difficulty to breathe (Alemu et al., 2013). Several of these studies mostly found no specific symptoms such that certain patients should be examined for their $\mathrm{CrAg}$, and concluded that all HIV/AIDS patients with low CD4+ T cell lymphocytes $(<200$ cells $/ \mu 1)$ in areas with high cryptococcus prevalence should undergo examination of $\mathrm{CrAg}$ without considering the patient's symptoms (Alemu et al., 2013; Rajasingham et al., 2017; Manga et al., 2016). There are also several other studies that show a strong association with neurological symptoms such as headache, conscious disorders and meningeal signs with $\mathrm{CrAg}$ positivity (Ganiem et al., 2014; Mamoojee et al., 2011).

From the 41 patients examined for $\mathrm{CD} 4+\mathrm{T}$ lymphocyte count, $95 \%$ of them had a CD4+ T cell lymphocyte count of $<100$ cells $/ \mu \mathrm{l} ; 5 \%$ had a CD4+ $\mathrm{T}$ cell lymphocyte count of $100-200$ cells/ $\mu$ l. Three patients with positive $\mathrm{CrAg}$ from this study had a CD4+ T cell lymphocyte count of $<100$ cells $/ \mu 1$, with a mean of 45.3 cells $/ \mu$. The average $\mathrm{CrAg}$ negative patient was 31.5 cells $/ \mu$ l. The inclusion criteria in this study were patients with a CD4+ T cell lymphocyte count of $<200$ cells/ $\mu 1$ with symptoms of fever and/or headache. These inclusion criteria were taken based on several studies on the previous prevalence of CrAg. Research conducted by Vidal et al. found a $21 \%$ prevalence of positive $\mathrm{CrAg}$ with a CD4+ T cell lymphocyte count of 100-200 cells/ $\mu$. A study 
conducted by Negroni et al. in the pre-ARV era achieved a prevalence rate of $6.2 \%$ in HIV/AIDS patients with a CD4+ T cell count of $<300$ cells $/ \mu 1$.

There was no significant difference of CD4+ T cell lymphocyte count (< 100 cell/ $\mu \mathrm{l} /$ 100-200 cells $/ \mu \mathrm{l})$ in CrAg positive and CrAg negative patients in this study $(\mathrm{p}=1.000)$. This may be due to the majority of the data showing a CD4+ $\mathrm{T}$ cell lymphocyte count at $<100$ cell $/ \mu \mathrm{l}$. Research conducted by Manga et al. (2016) also obtained the value of $\mathrm{p}>0.05$ ( $\mathrm{p} 0.3$ ). Research conducted by Alemu et al. (2013) obtained a p value of 0.28. On the other hand, research conducted by Ganiem et al. (2014) obtained a p value of 0.327 (Alemu et al., 2013; Manga et al., 2016; Ganiem et al., 2014).

With a CD4+ T lymphocyte count $<100$ cell $/ \mu 1$, more opportunistic infections can occur. The prevalence of opportunistic infections varies among regions (Gangcuangco et al., 2017). Opportunistic infections encountered in this study included pulmonary tuberculosis, cerebral toxoplasmosis, oropharyngeal candidiasis, and PCP. The most common types of opportunistic infections in this study were pulmonary tuberculosis. Research conducted by Andama et al. (2013) asserted that tuberculosis is an infection that is often encountered along with cryptococcus antigenemia. Indonesia is recognized to be a country with a high burden of tuberculosis, in addition to China and India (Andama et al., 2013). Several studies have suggested that tuberculosis itself may result in a decrease in cellular immune function (a decrease in CD4+ T lymphocyte count). Tuberculosis infection with HIV will result in a significantly lower CD4+ $\mathrm{T}$ lymphocyte count compared to HIV monoinfection or monoinfected tuberculosis (Pawlowski et al., 2012; Rajian et al., 2017). The number of patients who previously had received ARV was 15 subjects $(36.6 \%)$, 96\% of whom had CD4+ T cell lymphocytes $<100$ cells $/ \mu 1$. This may be due to non-routine ARV, as well as the emergence of antiretroviral resistance. In this study, positive CrAg was obtained in HIV/AIDS patients who had not received antiretroviral therapy; however, the calculations did not show statistically significant differences $(p=0.287)$. This was also found in a study conducted by Vidal et al. (2013) who revealed that the prevalence of $\mathrm{CrAg}$ positive in HIV/AIDS patients who had never received antiretroviral therapy of $2.4 \%$ is similar to the prevalence of positive $\mathrm{CrAg}$ in HIV/AIDS patients who had received antiretroviral drugs of 3.3\% (Vidal et al., 2013). Manga et al. (2016) obtained a $\mathrm{p}$ value of 0.1 in relation to $\mathrm{CrAg}$ cases with previous ARV status (Manga et al., 2016). This is not similar to the results of a study conducted in
Ethiopia that found that the prevalence of positive CrAg in HIV/AIDS patients who had never received ARV was $14.2 \%$ (18/127), whereas the prevalence of positive $\mathrm{CrAg}$ in HIV/AIDS patients who had received ARV was $4.1 \%(5 / 121)$ (Beyene et al., 2013).

In blood culture examination using Bactec aerob, bactec was positive in the first 24 hours in the first patient (Table 5.4), whereas bactec was negative in the second patient, and bactec was positive on the fifth day in the third patient. The aerobic bactec in the first patient grew in SDA after the tenth day and aerobic bactec in the third patient grew in SDA after the second day. There were cultured colonies which were mukoid textured and colored white to cream. In LCB staining and Indian ink, yeast cells appeared, the form being spherical and irregular, with capsule formation around the cells. Research conducted by Vidal et al. (2013) found one out of five HIV/AIDS patients with positive LFA CrAg results that also had positive blood cultures, while four other blood cultures were negative. This proves that LFA CrAg is more sensitive in diagnosing cryptococcus antigenemia (Vidal et al., 2013).

In this study, there was Cryptococcus neoformans (obtained in the third patient), while the other (from the first patient) could not be identified by species. The Vitek 2 system has been able to identify several species of cryptococcus fungi, including Cryptococcus albidus, Cryptococcus laurentii, Cryptococcus neoformans, Cryptococcus terreus, Cryptococcus uniguttulatus, but the system has not been able to identify Cryptococcus gattii. The identification of Cryptococcus gattii requires a molecular approach (Melhem et al., 2013). Therefore, based on positive LFA CrAg, colony cultures, LCB coloring and Indian ink coloring, the writers suspect that the first species was Cryptococcus gatti.

\section{CONCLUSION}

There was no association found between the occurrence of cryptococcal antigenemia (positive/negative) with a CD4+ T cell lymphocyte count $(100-200$ cells/ $\mu \mathrm{l} /<100$ cells/ $\mu \mathrm{l})$ in HIV/AIDS patients with suspected Cryptococcus infection in Dr. Soetomo General Hospital, Surabaya. The proportion of cryptococcal antigenemia in HIV/AIDS patients accompanied by suspected cryptococcus infection in Dr. Soetomo General Hospital Surabaya from March 2017 - June 2017 was 7.32\%. There was no association found between the occurrence of cryptococcal antigenemia (positive/negative) with 
age in HIV/AIDS patients with suspected Cryptococcus infection in Dr. Soetomo General Hospital, Surabaya. There was no association found between the occurrence of cryptococcal antigenemia (positive/negative) with gender in HIV/AIDS patients with suspected Cryptococcus infection in Dr. Soetomo General Hospital, Surabaya. There was no association found between the occurrence of cryptococcal antigenemia (positive/negative) with symptoms of fever and headache in HIV/AIDS patients with suspected Cryptococcus infection in Dr. Soetomo General Hospital, Surabaya. There was no association found between the occurrence of cryptococcal antigenemia (positive/negative) with previous antiretroviral (ever/never) status in HIV/AIDS patients with suspected Cryptococcus infection in Dr. Soetomo General Hospital, Surabaya. Cryptococcus examination using LFA method antigen detection is more sensitive and faster compared with fungal cultures.

\section{REFERENCES}

(UNAIDS)., J. U. N. P. O. H. A. 2015. Global statistics.

ALEMU, A. S., KEMPKER, R. R., TENNA, A., SMITSON, C. \& BERHE, N., FEKADE, D., ET AL. 2013. High Prevalence of Cryptococcal Antigenemia among HIVinfected Patients Receiving Antiretroviral Therapy in Ethiopia. Plos One ,. 8.

ANDAMA, A. O., SASKIA, B., MEYA, D. \& CATTANMANCHI, A., WORODRIA, W., DAVIS, J. L., ET AL. 2013. Prevalence and Outcomes of Cryptococcal antigenemia in HIV-seropositive Patients Hospitalized for Suspected Tuberculosis in Uganda. . JAIDS, , 63, 189-194. .

BEYENE, T., WOLDEAMANUEL, Y., ASRAT, D., AYANA, G. \& BOULWARE, D. R. 2013. Comparison of cryptococcal antigenemia between antiretroviral naive and antiretroviral experienced HIV positive patients at two hospitals in Ethiopia. PLoS One, 8, e75585.

DENNING, D. W. 2016. Minimizing fungal disease deaths will allow the UNAIDS target of reducing annual AIDS deaths below 500000 by 2020 to be realized. Philos Trans $R$ Soc Lond B Biol Sci, 371.

GANGCUANGCO, L. M. A., SAWADA, I., TSUCHIYA, N. \& DO, C. D., PHAM, T.T.T., ET AL. 2017. Regional Differences in the Prevalence of Major Opportunisitc Infections among Antiretroviral-Naive Human Immunodeficiency Virus Patients in Japan, Northern Thailand, Northen Vietnam and the Philippines. . Am J Trop Med Hyg, , 97, 49-56. .

GANIEM, A. R., INDRATI, A. R., WISAKSANA, R., MEIJERINK, H., VAN DER VEN, A., ALISJAHBANA, B. \& VAN CREVEL, R. 2014. Asymptomatic cryptococcal antigenemia is associated with mortality among HIV-positive patients in Indonesia. J Int AIDS Soc, 17, 18821.

GOVENDER, N. P., ROY, M., MENDES, J. F., ZULU, T. G., CHILlER, T. M. \& KARSTAEDT, A. S. 2015. Evaluation of screening and treatment of cryptococcal antigenaemia among HIV-infected persons in Soweto, South Africa. HIV Med, 16, 468-76.

KOZEL, T. R. \& BAUMAN, S. K. 2012. CrAg lateral flow assay for cryptococcosis. Expert Opin Med Diagn, 6, 245-51.

MAMOOJEE, Y., SHAKOOR, S., GORTON, R. L., SARFO, S., APPIAH, L. T., NORMAN, B., BALAKRISHNAN, I., PHILLIPS, R. \& CHADWICK, D. 2011. Short Communication: Low seroprevalence of cryptococcal antigenaemia in patients with advanced HIV infection enrolling in an antiretroviral programme in Ghana. Trop Med Int Health, 16, 53-6.

MANGA, N. M., DIALLO, V. M. P. C., BADIANE, N. M. D., NYAFOUNA, S. A. D., YENGO, D. E. R. N. \& NDOUR, C. T. E. A. 2016. Prevalence and Factors Associated with Positive Cryptococcal Antigenemia among HIV Infected Adult Hospitalized in Senegal. . Journal of HIV \& Retro Virus, , 2, 20. .

MCCLELLAND, E. E. \& HOBBS, L. M., RIVERA, J, ET AL. 2013. The role of host gender in the pathogeneis of Cryptococcus neoformans infections. Plos ONE 8:e63632.

MELHEM, M. S. C., BERTOLETTI, A., LUCCA, H. R. L. \& SILVA, R. B. O., MENEGHIN, F. A., SZESZS, M. W. 2013. Use of The VITEK 2 system to identify and test the antifungal susceptibility of clinically relevant yeast species. . Brazilian Jounal of Microbiology , 44, 1257-66. .

MEYA, D. B., MANABE, Y. C. \& CASTELNUOVO, B., ET AL. 2010. Cost-effectiveness of serum cryptococcal antigen screening to prevent deths among HIVinfected persons with a CD4+ cell count $<$ or $=100$ cells $/$ microL who start HIV therapy in resource-limited settings. . Clin Infect Dis 51:, 448-55.

MFINANGA, S., CHANDA, D., KIVUYO, S. L., GUINNESS, L., BOTTOMLEY, C., SIMMS, V., CHIJOKA, C., MASASI, A., KIMARO, G., NGOWI, B., KAHWA, A., MWABA, P., HARRISON, T. S., EGWAGA, S., JAFFAR, S. \& TEAM, R. T. 2015. Cryptococcal meningitis screening and communitybased early adherence support in people with advanced HIV infection starting antiretroviral therapy in Tanzania and Zambia: an open-label, randomised controlled trial. Lancet, 385, 2173-82.

PARKES, R. R., WAKEHAM, K. \& LEVIN, J., ET AL. 2011. Primary prophylaxis of cryptococcal disease with fluconazole in HIV-positive Ugandan adults: a doubleblind, randomised, placebo-controlled trial. . Lancet Infect Dis, , 11, , 933-41.

PAWLOWSKI, A., JANNSON, M., SKOLD, M., ROTTENBERG, M. E. \& KALLENIUS, G. 2012. Tuberculosis and HIV Co-Infection. PloS Pathog,, 8.

RAJASINGHAM, R., SMITH, R. M., PARK, B. J., JARVIS, J. N., GOVENDER, N. P. \& CHILLER, T. 
M., DENNING, D. W., LOYSE, A., BOULWARE, D. 2017. Lancet Infect Dis. .

RAJIAN, M., GILL, P. S. \& CHAUDHARY, U. 2017. Effect of Tuberculosis co infection on Virological Failure in HIV patients on First Line of Highly Active Antiretroviral Therapy. . Int. J. Curr. Microbiol. App.Sci. , , 6, 78-81.

RI., K. K. 2014. Pusat Data dan Informasi Kementerian Kesehatan RI. Situasi dan Analisis HIV AIDS. .

TENSINI, T. S., MURO, M. D., TELlES, F. Q. \& STROZZI, I., MORAES, S. T., PETTERLE, R.R. 2016. Geographic distribution of patients affected by crytpococcus neoformans/cryptococcus gattii species complexes meningitis, pigeon and tee populations in Southern Brazil. .

VIDAL, J. E., PENALVA, A. C., DAUAR, R. F. \& BOULWARE, D. R. 2013. Strategies to reduce mortality and morbidity due to AIDS-related cryptococcal meningitis in Latin America. . Braz $J$ Infect Dis, , 17, .

VIDAL, J. E., TONIOLO, C., PAULINO, A., COLOMBO, A., DOS ANJOS MARTINS, M., DA SILVA MEIRA, C., PEREIRA-CHIOCCOLA, V. L., FIGUEIREDOMELLO, C., BARROS, T., DUARTE, J., FONSECA, F., ALVES CUNHA, M., MENDES, C., RIBERO, T., DOS SANTOS LAZERA, M., RAJASINGHAM, R. \& BOULWARE, D. R. 2016. Asymptomatic cryptococcal antigen prevalence detected by lateral flow assay in hospitalised HIV-infected patients in Sao Paulo, Brazil. Trop Med Int Health, 21, 1539-1544. 